\title{
Detection of Muramic Acid in a Carbohydrate Fraction of Human Spleen
}

\author{
MAARTEN A. HOIJER,,${ }^{1 *}$ MARIE-JOSÉ MELIEF, ${ }^{1}$ CORNELIA G. vAN HELDEN-MEEUWSEN,${ }^{1}$ \\ FRITS EULDERINK, ${ }^{2}$ AND MAARTEN P. HAZENBERG ${ }^{1}$ \\ Department of Immunology, Erasmus University, Rotterdam, ${ }^{1}$ and Diagnostisch centrum SSDZ, \\ Delft, ${ }^{2}$ The Netherlands
}

Received 6 October 1994/Returned for modification 12 December 1994/Accepted 29 January 1995

\begin{abstract}
In previous studies, we showed that peptidoglycan polysaccharides from anaerobic bacteria normally present in the human gut induced severe chronic joint inflammation in rats. Our hypothesis is that peptidoglycan from the gut flora is involved in perpetuation of idiopathic inflammation. However, in the literature, the presence of peptidoglycan or subunits like muramyl peptides in blood or tissues is still a matter of debate. We were able to stain red pulp macrophages in all six available human spleens by immunohistochemical techniques using a monoclonal antibody against gut flora-derived antigens. Therefore, these human spleens were extracted, and after removal of most of the protein, the carbohydrate fraction was investigated for the presence of muramic acid, an amino sugar characteristic for peptidoglycan. Using three different methods for detection of muramic acid, we found a mean of $3.3 \mu \mathrm{mol}$ of muramic acid with high-pressure liquid chromatography, $1.9 \mu \mathrm{mol}$ with a colorimetric method for detection of lactate, and $0.8 \mu \mathrm{mol}$ with an enzymatic method for detection of D-lactate per spleen (D-lactate is a specific group of the muramic acid molecule). It is concluded that peptidoglycan is present in human spleen not as small muramyl peptides as were previously searched for by other investigators but as larger macromolecules probably stored in spleen macrophages.
\end{abstract}

Muramic acid (Mur) is one of the two amino sugars in the glycan backbone of peptidoglycan (murein). It is mostly present in an acetylated form, i.e., $N$-acetylmuramic acid. Short peptides are linked to the lactyl groups of this molecule, forming a large complex macromolecule which surrounds the cell as a basket around the cell membrane (29). In this study, Mur was used as a chemical marker for peptidoglycan polymers. Sen and Karnovsky (20) showed the qualitative detection of muramic acid in normal mammalian tissues. Fox and Fox (5) were not able to detect Mur in normal serum, which demonstrates the absence of appreciable amounts of circulating natural muramyl peptides. Our group is interested in the presence of peptidoglycan in tissues, as we believe that such intestinal flora derived carbohydrates are important for physiological and immunological functions in the host. Johannsen et al. $(11,12)$ showed that muramyl peptides have a variety of biological actions in mammals, including the ability to enhance sleep and body temperature. In the last 15 years, many authors have described biological activities of peptidoglycan in vivo and in vitro, all indicating that peptidoglycan can influence cells like lymphocytes and macrophages which are involved in inflammation. Lichtman et al. (15) showed that livers of rats injected intraperitoneally with peptidoglycan were able to reactivate arthritis after transplantation into a second rat with preinjured joints. They postulate that peptidoglycan present in the liver is redistributed to other tissues, including the injured joints, where it causes reactivation of arthritis. From the studies done by Lichtman et al., it seemed obvious to look for large bacterial fragments in human tissues. Our group is investigating the relationship between arthritis and intestinal bacteria (9). By using a rat model, the arthropathic properties of cell wall fragments of a number of obligate anaerobic bacteria belong-

\footnotetext{
* Corresponding author. Mailing address: Department of Immunology, Erasmus University, P.O. Box 1738, 3000 DR Rotterdam, The Netherlands. Phone: 31-10-408.7800. Fax: 31-10-436.7601.
}

ing to the major residents of the intestinal flora were described (14, 21-23). Recently, we developed a monoclonal antibody against a bacterial flora-derived peptidoglycan polysaccharide fraction from human feces and found positive staining of rat spleen macrophages (13). Therefore, we have strong support for the presence of bacterial flora-derived products in the spleen. In this study, we analyzed six surgically removed human spleens. Using colorimetric Mur analysis, enzymatic determination of D-lactic acid, and high-pressure liquid chromatography (HPLC) analysis, we demonstrated the presence of substantial amounts of Mur. We concluded that peptidoglycan polymers are present in human spleen.

\section{MATERIALS AND METHODS}

Spleen. Six sterile unfixed human spleens were obtained from the pathology department immediately after surgery (SSDZ, Delft, The Netherlands) and kept frozen until use. The spleen was removed from each of five patients (patients 1 through 5) with gastric adenocarcinomas for technical reasons and from patient 6 because of traumatic rupture. Spleen samples were aerobically and anaerobically cultured on blood agar base during $48 \mathrm{~h}$ at $37^{\circ} \mathrm{C}$. No bacterial growth was observed. The anaerobic plates were cultured in a jar supplied with GasPak generator envelopes with palladium catalyst (Becton Dickinson).

Immunological staining. Immunohistologic staining of the human spleen was performed according by the method of Kool et al. used for the staining of rat spleen (13). The same monoclonal antibody, 2E9 (mouse immunoglobulin G3), recognizing intestinal flora derived peptidoglycan polysaccharides was used. Staining was also performed with $2-4$, a monoclonal antibody recognizing muramyl dipeptide as described by Bahr et al. (1).

Spleen extraction. For spleen extraction (Fig. 1), 50 to $100 \mathrm{~g}$ of minced spleen in 500 to $1,000 \mathrm{ml}$ of $\mathrm{H}_{2} \mathrm{O}$ was homogenized in portions by a Virtis homogenizer (Virtis Company) at $10,000 \mathrm{rpm}$ for $30 \mathrm{~s}$. The homogenate was sonicated five times for 1 min each at maximum amplitude (MSE Soniprep 150). Acetic acid $(96 \%)$ was added to a final concentration of $0.2 \mathrm{M}$. The extract was incubated at room temperature for $2 \mathrm{~h}$ under rotation and was subsequently heated gradually in a water bath to $100^{\circ} \mathrm{C}$ over a period of $30 \mathrm{~min}$. The extract was centrifuged at $10,000 \times g$. The volume of the supernatant was reduced by lyophilization to 25 to $50 \mathrm{ml}$, and the extract was then centrifuged at $100,000 \times g$. The supernatants (15-ml portions) were separated by gel filtration on a $275-\mathrm{ml}$ gel bed of Sephadex G-25 (Pharmacia, Uppsala, Sweden). Mur and protein were determined in all fractions by the methods of Hadzija (7) and Bradford (2). The high-molecularweight fraction was collected and loaded onto a Dowex $50 \mathrm{~W} \times 4$ column (Fluka Chemie AG, Buchs, Switzerland) equilibrated in $0.1 \mathrm{M}$ acetic buffer (pH 4.6) for 
$50-100 \mathrm{~g}$ human spleen in 10 vol. $\mathrm{H}_{2} \mathrm{O}$

$\downarrow$

mincing, homogenization, sonication

$\downarrow$

acetic acid $(0.2 \mathrm{M})$ extraction and $100^{\circ} \mathrm{C}$ heating

$\downarrow$

$10,000 \times g$, reduction of supernatant, $100,000 \times g$

$\downarrow$

Sephadex G-25 gel filtration of $15 \mathrm{ml}$ supernatant aliquots

$\downarrow$

Ion exchange chromatography (Dowex $50 \mathrm{~W} \times 4$ ) of high molecular weight fractions

$\downarrow$

reduction of volume, dialysis against $\mathrm{H}_{2} \mathrm{O}, 100,000 \times g$

$\downarrow$

$10 \mathrm{ml}$ supernatant referred to as $A$

$\downarrow$

DEAE sepharose CL-6B

$\downarrow$

dialysis, reduction of volume

referred to as B

$\downarrow$

- HPLC analysis of aminosugars for

determination of Mur

$\downarrow$

Table 2

FIG. 1. Flow diagram of the extraction and purification of a Mur-containing fraction from human spleen. further protein reduction. The volume of the pooled fractions was reduced by lyophilization to $10 \mathrm{ml}$, and this preparation was dialyzed against $1 \mathrm{dm}^{3}$ of $1 \mathrm{M}$ $\mathrm{NaCl}$ and thereafter three times against $3 \mathrm{dm}^{3}$ of $\mathrm{H}_{2} \mathrm{O}$ (bidest). After centrifugation at $100,000 \times g$, the supernatant was stored and used for determination of Mur (see below). This preparation is further referred to as A. For HPLC analysis of Mur, a further removal of protein was necessary. Therefore, a DEAE-Sepharose CL-6B (Pharmacia) gel bed of $22 \mathrm{ml}$ was washed with $0.5 \mathrm{M} \mathrm{NaCl}$ followed by a large volume of $\mathrm{H}_{2} \mathrm{O}$. Then $5 \mathrm{ml}$ of preparation $\mathrm{A}$ was loaded onto the column and eluted with $\mathrm{H}_{2} \mathrm{O}$ until no more protein was detected. A $15-\mathrm{ml}$ Mur-containing fraction was collected after elution with $0.5 \mathrm{M} \mathrm{NaCl}$. This $15-\mathrm{ml}$ sample was dialyzed against $\mathrm{H}_{2} \mathrm{O}$, lyophilized, and dissolved in $2 \mathrm{ml}$ of $\mathrm{H}_{2} \mathrm{O}$. This preparation is further referred to as B. In preparation B Mur, protein and total carbohydrates (17) were determined.

Determination of Mur. (i) Preparation A. Mur was determined by the method of Hadzija (7), with some modifications (8). In short, samples were hydrolyzed by heating for $2 \mathrm{~h}$ at $90^{\circ} \mathrm{C}$ with an equal volume of $5 \mathrm{M} \mathrm{H}_{2} \mathrm{SO}_{4}$ and then neutralized with $10 \mathrm{M} \mathrm{NaOH}$. Hydrolyzed and unhydrolyzed samples $(100 \mu \mathrm{l})$ were incubated with $50 \mu \mathrm{l}$ of $1 \mathrm{M} \mathrm{NaOH}$ at $36^{\circ} \mathrm{C}$ for $30 \mathrm{~min}$. After the addition of $1 \mathrm{ml}$ of $18.8 \mathrm{M} \mathrm{H}_{2} \mathrm{SO}_{4}$ (concentrated), samples were heated for $3.5 \mathrm{~min}$ at $100^{\circ} \mathrm{C}$, rapidly cooled in ice, and then mixed with $10 \mu \mathrm{l}$ of $0.16 \mathrm{M} \mathrm{CuSO}_{4} 5 \cdot \mathrm{H}_{2} \mathrm{O}$ in $\mathrm{H}_{2} \mathrm{O}$ and 20 $\mu \mathrm{l}$ of $0.09 \mathrm{M} p$-hydroxydiphenyl in ethanol. The blue color developed to a maximum in $30 \mathrm{~min}$ at $30^{\circ} \mathrm{C}$. $A_{570}$ was determined with a Titertek Multiskan (Flow Laboratories, Irvine, Scotland). Solutions containing 0 to $100 \mu \mathrm{g}$ of Mur (Sigma, St. Louis, Mo.) per $\mathrm{ml}$ of $\mathrm{H}_{2} \mathrm{O}$ were used as standards. The data are given as the difference in concentration between the hydrolyzed and nonhydrolyzed samples. In this way, only Mur linked to the peptides in peptidoglycan is determined, and disturbing sugars like rhamnose and of course of lactic acid itself, which are determined in the nonhydrolyzed sample, can be excluded. The presence of Mur in preparation A was also determined by measurement of D-lactic acid by the method of Tipper (26). Two milliliters of preparation A was hydrolyzed with $2 \mathrm{ml}$ of $12 \mathrm{M} \mathrm{HCl}$ at $90^{\circ} \mathrm{C}$ for $2 \mathrm{~h}$. The sample was lyophilized and dissolved in $1 \mathrm{ml}$ of $\mathrm{H}_{2} \mathrm{O}$. D-Lactate was determined by enzymatic bioanalysis of D-lactic acid-L-lactic acid (Boehringer Mannheim GmbH, Mannheim, Germany). (ii) Preparation B. The presence of Mur was determined with an amino acid amino sugar determination using reverse-phase HPLC techniques as described by Glauner (6). In short, for dansylation of preparation B, $1 \mathrm{ml}$ was hydrolyzed with $500 \mu \mathrm{l}$ of $12 \mathrm{M} \mathrm{HCl}$ for $3 \mathrm{~h}$ at $90^{\circ} \mathrm{C}$. The sample was frozen, lyophilized, and redissolved in $100 \mu \mathrm{l}$ of $\mathrm{H}_{2} \mathrm{O}$. This sample was added to $100 \mu \mathrm{l}$ of $200 \mathrm{mM}$ borate buffer ( $\mathrm{pH} 8.8$ ) and $100 \mu \mathrm{l}$ of $20 \mathrm{mM}$ dansyl chloride (5-dimethylamino-naphthalene-1-sulfonyl chloride; Fluka) in acetone and allowed to react for $2 \mathrm{~h}$ at $37^{\circ} \mathrm{C}$. The reaction was stopped with $200 \mathrm{mM}$ phosphoric acid. Valine was used as an internal standard, and all other standard amino acids (Sigma) underwent the same treatment.

Separation of dansylated amino acids and amino sugars was accomplished by reverse-phase HPLC. Samples were analyzed with a Pharmacia-LAB 2248 singlepump solvent delivery system and VWM 2141 UV-VIS monitor both connected to a computer working with HPLC Manager software to control the pump, gradient mixer, and UV-VIS detector operating at $330 \mathrm{~nm}$. Integration and analysis of chromatograms was performed with the same software (Pharmacia). Dansylated samples were separated on a Pharmacia SuperPac Sephasil $\mathrm{C}_{18}$ column $(5 \mu \mathrm{m}, 4$ by $250 \mathrm{~mm})$. The flow rate used was $1 \mathrm{ml} / \mathrm{min}$, and the buffers used were $\mathrm{A}(20 \mathrm{mM}$ sodium phosphate $[\mathrm{pH} 5.25])$ and $\mathrm{B}(60 \%$ acetonitrile, $40 \%$ $50 \mathrm{mM}$ sodium phosphate $[\mathrm{pH} 4.0])$. At $0,10,16,21.5,22$, and $27 \mathrm{~min}$, the percentages of preparation B were $30,50,100,100,30$, and 30 , respectively.

Eluted products were detected at $330 \mathrm{~nm}$, the wavelength which is maximally absorbed by the dansyl groups. Internal standard valine and external standards valine and Mur were used for calculating Mur contents of the spleen samples.

\section{RESULTS}

Immunohistochemistry of the spleen. Red pulp macrophages in the six spleens were immunohistochemically stained. Figure 2 shows an immunohistologic staining of a human spleen with monoclonal antibody $2 \mathrm{E} 9$ recognizing intestinal 


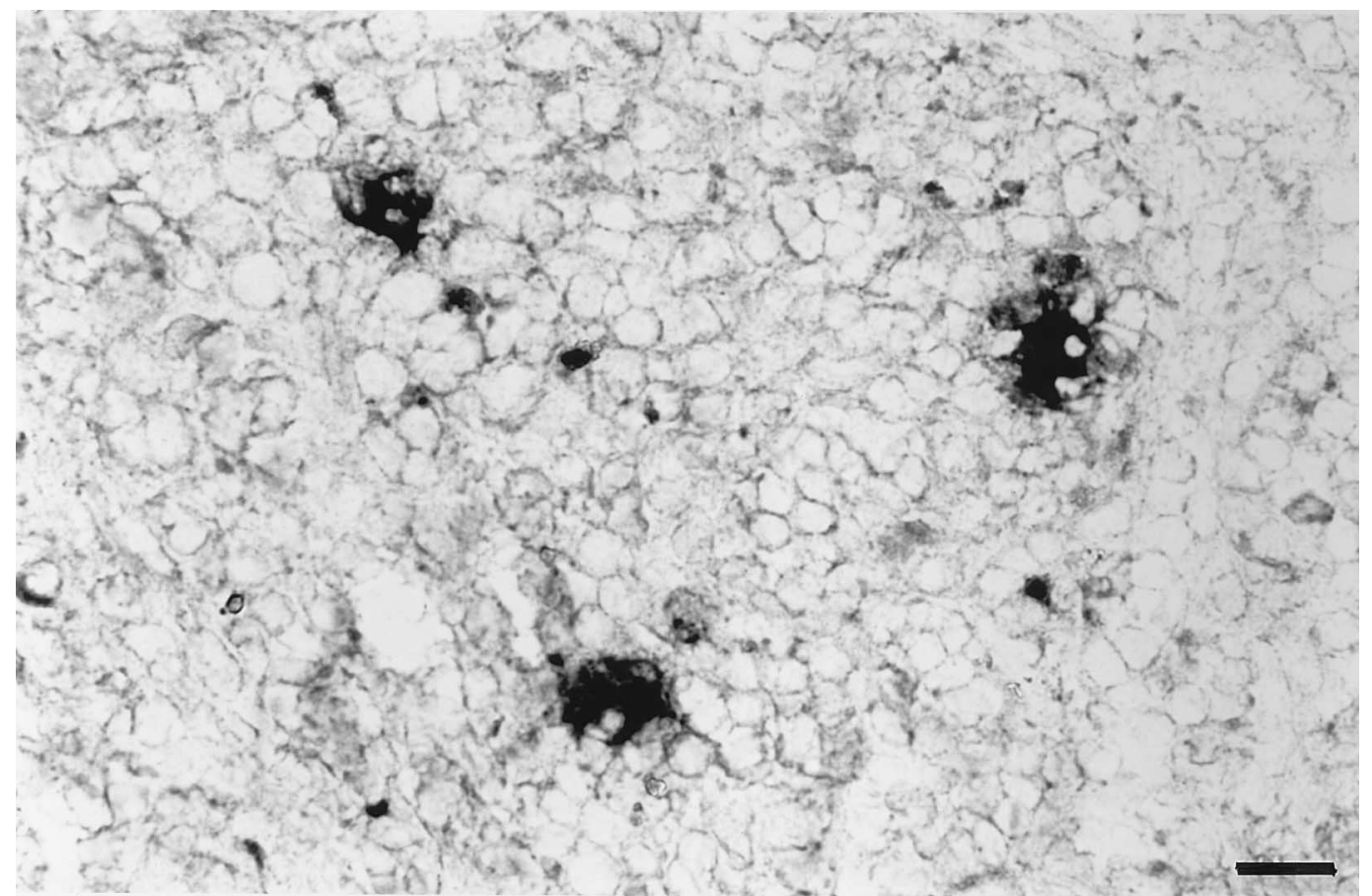

FIG. 2. Immunohistologic staining with monoclonal 2E9 of human spleen. Three large 2E9-positive macrophages are stained black. Bar, $21.8 \mu \mathrm{m}$.

flora-derived peptidoglycan polysaccharides. Monoclonal antibody $2-4$, recognizing muramyl dipeptide, also stained cells in these spleens (not shown). Negative control antibody NS7 of the same isotype, mouse immunoglobulin G3, and with irrelevant specificity did not stain the spleens. From these positive results, we concluded that bacterial antigens were present in each of the spleens and that these could be used for isolation of a particular bacterial fraction.

Purification of Mur fraction from spleen. From all six spleens, preparation A was isolated as described above. The general outlines of the procedure are depicted in Fig. 1. Figure 3 shows the elution pattern after Sephadex G-25 gel filtration of the extracted spleen from patient 1 . Protein was found after an elution volume of $95 \mathrm{ml}$ of $\mathrm{H}_{2} \mathrm{O}$. Mur was detected after an elution volume of $85 \mathrm{ml}$ of $\mathrm{H}_{2} \mathrm{O}$ and increased to a maximum of $32 \mu \mathrm{g}$ of Mur per ml. Then it decreased and finally sharply increased to a level much higher than $100 \mu \mathrm{g} / \mathrm{ml}$. We pooled the fractions between 85 and $130 \mathrm{ml}$, which represented a relatively high-molecular-weight fraction, and discarded the low-molecular-weight fraction because it contained lactate, which disturbed the colorimetric Mur assay. The pool was loaded on a strong cation-exchange column, Dowex $50 \mathrm{~W} \times 4$, which bound $90 \%$ of the protein. After this step, the volume was reduced and the preparation was dialyzed. In a pilot experiment, samples of lysozyme-solubilized cell wall fragments of Eubacterium aerofaciens (22), a carbohydrate polymer with

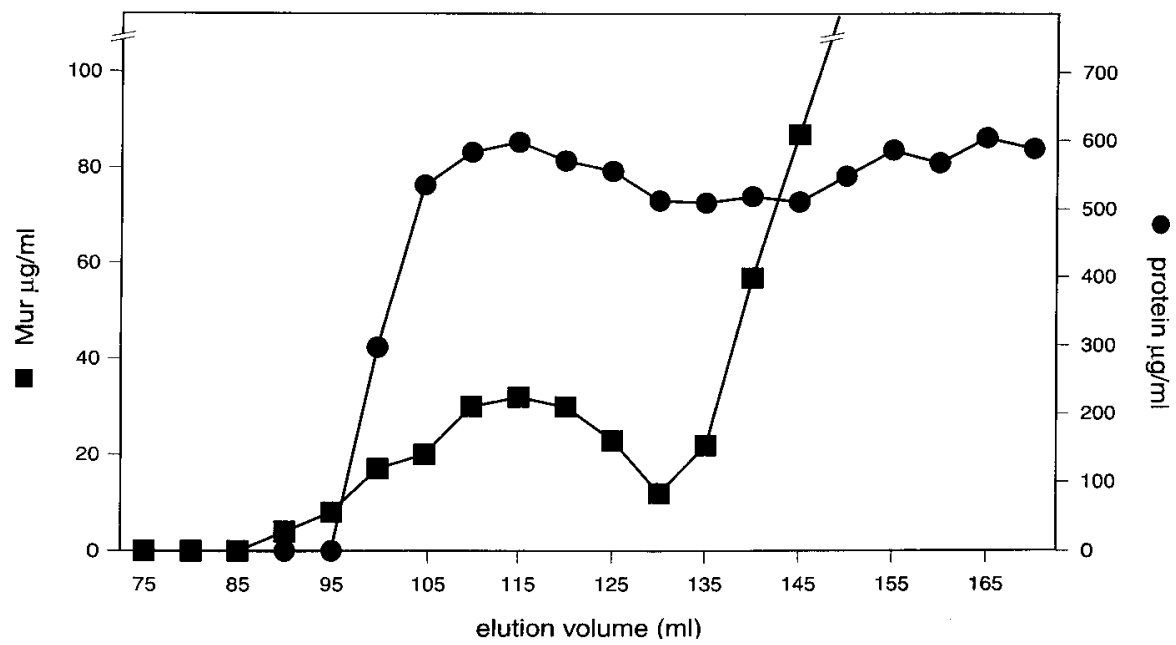

FIG. 3. Separation of high- and low-molecular-weight fractions by Sephadex G-25 gel filtration of an extract of human spleen of patient 1 . In step 5 in Fig. 1 , 15 $\mathrm{ml}$ of spleen extract was loaded onto a $275-\mathrm{ml}$ gel bed of a Sephadex G-25 column, and Mur and protein concentrations were determined in the fractions. 
TABLE 1. Recovered Mur determined according to Hadzija (modified) and Tipper methods in preparation A from six human spleen extractions

\begin{tabular}{cccc}
\hline & $\begin{array}{c}\text { Spleen wet wt } \\
(\mathrm{g})\end{array}$ & \multicolumn{2}{c}{$\begin{array}{c}\text { Mur }(\mu \mathrm{mol}) \text { as determined } \\
\text { by the method of: }\end{array}$} \\
\cline { 3 - 4 } & & Hadzija & Tipper \\
\hline 1 & 91 & 2.82 & 0.97 \\
2 & 70 & 2.27 & 0.75 \\
3 & 55 & 2.29 & 0.38 \\
4 & 93 & 2.66 & 0.40 \\
5 & 57 & 1.79 & 0.43 \\
6 & 73 & 2.56 & 2.04 \\
\hline
\end{tabular}

$20 \%$ (dry weight) Mur, were completely recovered in the corresponding fractions after the Sephadex G-25 gel filtration and for $80 \%$ after the Dowex chromatography.

From all spleens, $10 \mathrm{ml}$ of preparation A was prepared. In preparation $\mathrm{A}$, the protein concentration was still 0.5 to 1.5 $\mathrm{mg} / \mathrm{ml}$. The concentration Mur was determined by the method of Hadzija (7) with and without hydrolysis of the samples, and the net values are given in Table 1. Mur was also determined by using D-lactic acid dehydrogenase as described by Tipper (26). Table 1 shows that in all preparations, the concentrations determined with the colorimetric method were higher than those found with the enzymatic method. Using E. aerofaciens cell wall fragments, we found twice as much Mur with the colorimetric method as with the enzymatic method of Tipper. Because both determinations of Mur are based on the presence of the lactyl group in Mur, we felt that a completely different assay for Mur should be used to confirm the results. Therefore, HPLC analysis of Mur was used. Since the method is based on a separation of dansylated amino acids and amino sugars, the preparation must be as free as possible from disturbing protein amino acids. Therefore, the remains of preparation A from spleens 1 to 5 were further purified by DEAE anion-exchange chromatography. The E. aerofaciens cell wall polymers applied to the DEAE column showed that the protein part of the preparation was not bound. The Mur-containing fraction, however, did bind and could be eluted from the column with $0.5 \mathrm{M} \mathrm{NaCl}$. DEAE passage of preparation A reduced the protein contents considerably $(<200 \mu \mathrm{g} / \mathrm{ml})$. In this sample, called preparation B, Mur, protein, and total carbohydrate concentrations were determined with colorimetric assays, and the results are shown in Table 2.

Samples of preparation B of spleens 1 to 5 were applied to HPLC. The strategy that we used for Mur detection by HPLC was as follows. First, by adding a little dansylated muramic acid to the sample, it was possible to spike a peak with a retention time of $11.3 \mathrm{~min}$ in the spleen sample, as depicted in Fig. 4A and $\mathrm{B}$. There are many peaks in the chromatogram, and there-

TABLE 2. Mur, protein, and total carbohydrates in preparation B from five human spleen extractions

\begin{tabular}{|c|c|c|c|c|}
\hline \multirow[b]{2}{*}{ Spleen } & \multicolumn{2}{|c|}{ Mur $(\mu \mathrm{M})$} & \multirow{2}{*}{$\begin{array}{l}\text { Protein } \\
(\mu \mathrm{g} / \mathrm{ml})\end{array}$} & \multirow{2}{*}{$\begin{array}{c}\text { Carbohydrates } \\
\qquad(\mu \mathrm{g} / \mathrm{ml})\end{array}$} \\
\hline & $\begin{array}{l}\text { Hadzija } \\
\text { method }\end{array}$ & HPLC & & \\
\hline 1 & 2.64 & 5.28 & 564 & 3,320 \\
\hline 2 & 1.40 & 3.56 & 352 & 2,000 \\
\hline 3 & 1.04 & 2.16 & 412 & 2,000 \\
\hline 4 & 3.60 & 4.40 & 368 & 5,080 \\
\hline 5 & 0.76 & 1.32 & 780 & 1,240 \\
\hline
\end{tabular}

fore we decided to collect the peak with retention time 11.3 min and reanalyze this peak to see if it really has the same retention time as the standard dansyl Mur. Indeed, a major peak of the chromatogram of the collected peak had exactly the same retention time as dansyl Mur (Fig. 4C and D). Finally, we determined Mur in the collected peak by using the colorimetric assay of Hadzija to complete the circle and prove that the spleen samples contain Mur.

Calculations of Mur concentration by using valine as an internal standard gave results in the same range as the other method but may have been hampered by contaminating protein amino acids (Table 2). When the results of Mur concentrations (Tables 1 and 2) are summarized as mean values, then with HPLC $3.3 \mu \mathrm{mol}$, with the Hadzija method $1.9 \mu \mathrm{mol}$ (preparation B) and $2.4 \mu \mathrm{mol}$ (preparation A), and with the Tipper method $0.8 \mu \mathrm{mol}$ per spleen (average, $73 \mathrm{~g}$ ) were found.

\section{DISCUSSION}

Sen and Karnovsky found 100 pmol of Mur per g of rat liver tissue and extracted muramyl compounds from brain and kidney (20). A daily output of $1 \mu \mathrm{mol}$ of free diaminopimelic acid, an amino acid specific for muramyl peptides, was found in human urine by Johannsen and Krueger (10). Fox and Fox, however, could not detect Mur in human serum and therefore considered the presence of peptidoglycan- or Mur-containing subunits a matter of dispute (5). In this study, we determined Mur in spleen tissue by three different methods. The spleen was chosen because a previous immunohistochemical study with monoclonal antibodies showed the presence of bacterial antigen in macrophages in the rat spleen (13). The six human spleens used in this study also contained macrophages positively stained by monoclonal antibody 2E9. Specificity of the monoclonal antibody was checked by inhibition enzyme-linked immunosorbent assays and by inhibition of immunohistologic staining of the spleens. Peptidoglycan polysaccharides were used as antigens.

The isolation procedure was focused on detecting Mur in polymeric peptidoglycan because that is the product which we think is present in the splenic macrophages, given our observations in rats injected with peptidoglycan polysaccharides from E. aerofaciens (13). Small muramyl dipeptide administered in vivo in mice, however, is excreted unchanged in the urine within minutes (27). The practical advantage of this assumption is that during the extraction and purification, the low-molecular-weight fraction could be discarded. In this respect, our study differed from the studies of Sen and Karnosky (20), who were looking for low-molecular-weight muropeptides. Before and after homogenization of the spleen tissues, sterility was checked by cultivating the homogenate on a blood agar plate. No contamination could be detected. Acetic acid extraction was used to hydrolyze the lysosomes in the spleen homogenates in which the peptidoglycan might be located (19). After this, the aim was to remove as much protein as possible while keeping the carbohydrate fraction. In the end, we succeeded in isolating such a fraction containing a considerable amount of Mur. Mur was used as a marker for the presence of polymers of peptidoglycan because Mur is considered to be unique for peptidoglycan.

We used three determination methods for Mur. (i) The method of Hadzija (7) (modified by Hazenberg et al. [8]) is based on the colorimetric determination of the lactyl group after acid hydrolyzes to remove peptides in peptidoglycan and treatment with $\mathrm{NaOH}$ to hydrolyze the ether bond of the lactyl group in Mur.

(ii) The method of Tipper (26) was also used. D-Lactic acid 

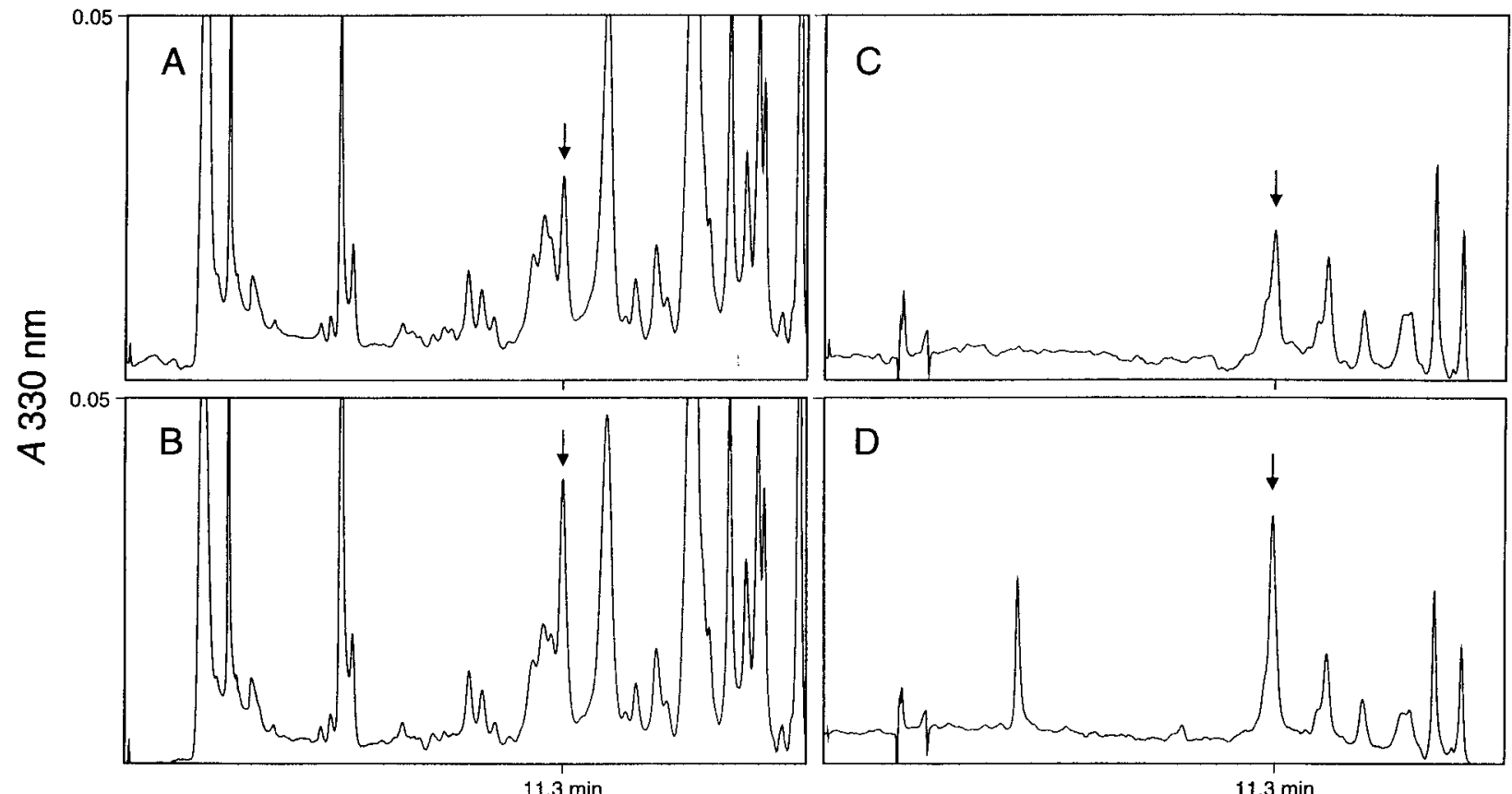

FIG. 4. Identification of Mur in preparation B from patient 1 by reverse-phase HPLC on a $\mathrm{C}_{18}$ column $(5 \mu \mathrm{m} ; 4$ by $250 \mathrm{~mm})$ in a discontinuous gradient of 0 to $15 \%$ methanol over $27 \mathrm{~min}$ at $1.0 \mathrm{ml} / \mathrm{min}$ of hydrolyzed and dansylated preparation B of spleen extract from patient 1. (A). (B) Same as panel A but spiked with dansylated Mur. (C) Collected peak with a retention time of $11.3 \mathrm{~min}$ from panel A. (D) Same as panel C but spiked with dansylated Mur. $A_{330}$ was measured. The peak with a retention time of 11.3 min, identified as Mur, is indicated $(\downarrow)$.

is specific for bacteria (24), and the covalent ether bond of D-lactic acid in Mur is very specific for this molecule and therefore for peptidoglycan. We adopted the method of Tipper, in which lactate dehydrogenase is used for the detection of D-lactic acid in peptidoglycan liberated after acid and alkali hydrolysis. Indeed, D-lactate was found in our E. aerofaciens cell wall fragment preparation after consecutive acid and alkalic hydrolysis (data not shown).

(iii) Because both methods for determination of Mur are based on detection of the (D) lactyl group, a third method not dependent on the presence of lactic acid was used. The HPLC analysis of amino sugars was carried out by a modified procedure developed by Glauner (6), who studied the composition of peptidoglycan of Escherichia coli extensively. After collection of the peaks with a retention time of 11.3 min (Fig. 4), we were able to determine Mur in this fraction with the Hadzija method. We conclude that in the human spleen Mur and therefore peptidoglycan is present not as small muramyl peptides as were previously looked for but as larger molecules probably stored in spleen macrophages.

Peptidoglycan has many biological effects in vivo; they include sleep induction (16), complement activation (30), adjuvant activity (4), and many other immunostimulatory effects such as antibody production (28) and T-cell-mediated arthritis induction $(9,14,21-23)$. In vitro peptidoglycans are able to stimulate human monocytes to produce tumor necrosis factor alpha and interleukin-1 and inhibition or activation of monocyte migration $(18,25)$. From the results presented in this report and results from other investigators, it can be concluded that our body tissues are continuously exposed to these bacterial products which in some cases might lead to biological activities in vivo. If so, this in its turn might provide a clue to inflammation with unknown etiology, such as rheumatoid arthritis and reactive arthritis. Presently we are investigating the biological properties of this peptidoglycan.

\section{ACKNOWLEDGMENTS}

We gratefully thank Tar van Os and Marjo van Everdingen-Quartel for excellent assistance in preparation of the manuscript.

\section{REFERENCES}

1. Bahr, G. M., Z. Eshar, R. Ben-Yitzhak, F. Z. Modabber, R. Arnon, M. Sela, and L. Chedid. 1983. Monoclonal antibodies to the synthetic adjuvant muramyl dipeptide: characterization of the specificity. Mol. Immunol. 20:745752.

2. Bradford, M. M. 1976. A rapid and sensitive method for the quantitation of microgram quantitic protein utilizing the principle of protein-dye binding. Anal. Biochem. 72:248-254.

3. Cromartie, W. J., J. G. Craddock, J. H. Schwab, S. K. Anderle, and C. H. Yang. 1977. Arthritis in rats after systemic injection of streptococcal cells or cell walls. J. Exp. Med. 146:1585-1602.

4. Ellouz, F., A. Adam, R. Ciorbaru, and E. Lederer. 1974. Minimal structure requirements for adjuvant activity of bacterial peptidoglycan derivatives. Biochem. Biophys. Res. Commun. 59:1317-1325.

5. Fox, A., and K. Fox. 1991. Rapid elimination of a synthetic adjuvant peptide from the circulation after systemic administration and absence of detectable natural muramyl peptides in normal serum at current analytical limits. Infect. Immun. 59:1202-1207.

6. Glauner, B. 1982. Analyse des Mureins von Escherishia coli mit Hilfe der Hochdruckflüssigkeitschromatographie. Diplomarbeit. Tübingen, Germany.

7. Hadzija, O. 1974. A simple method for the quantitive determination of muramic acid. Anal. Biochem. 50:512-517.

8. Hazenberg, M. P., and H. de Visser. 1992. Assay for N-acetylmuramyl-Lalanine amidase in serum by determination of muramic acid released from the peptidoglycan of Brevibacterium divaricatum. Eur. J. Clin. Biochem. 30:141-144.

9. Hazenberg, M. P., I. S. Klasen, J. Kool, J. G. H. Ruseler-van Embden, and A. J. Severijnen. 1992. Are intestinal bacteria involved in the etiology of rheumatoid arthritis? APMIS 100:1-9.

10. Johannsen, L., and J. M. Krueger. 1988. Quantitation of diaminopimelic acid in human urine. Adv. Biosci. 68:445-449.

11. Johannsen, L., L. A. Toth, R. S. Rosenthal, M. R. Opp, F. Obal, A. B. Cady, and J. Krueger. 1990. Somnogenic, pyrogenic, and hematologic effects of bacterial peptidoglycan. Am. J. Physiol. 259:R182-R186.

12. Johannsen, L., J. Wecke, F. Obal, and J. M. Krueger. 1991. Macrophages produce somnogenic and pyrogenic muramyl peptides during digestion of staphylococci. Am. J. Physiol. 260:R126-R133.

13. Kool, J., H. de Visser, M. Y. Gerrits-Boeye, I. S. Klasen, M.-J. Melief, C. G. 
van Helden-Meeuwsen, L. M. C. van Lieshout, J. G. H. Ruseler-van Embden, W. B. van den Berg, G. M. Bahr, and M. P. Hazenberg. 1994. Detection of intestinal flora derived bacterial antigen complexes in splenic macrophages of rats. J. Histochem. Cytochem. 42:1435-1441.

14. Kool, J., A. J. Severijnen, I. S. Klasen, M. Y. Gerrits-Boeye, and M. P. Hazenberg. 1992. Influence of decontamination on induction of arthritis in Lewis rats by cell wall fragments of Eubacterium aerofaciens. Arthropathic properties of indigenous anaerobic bacteria. Ann. Rheum. Dis. 51:510-515.

15. Lichtman, S. N., S. Bachmann, S. R. Munoz, J. H. Schwab, D. E. Bender, R. B. Sartor, and J. J. Lemasters. 1993. Bacterial cell wall polymers (peptidoglycan-polysaccharide) cause reactivation of arthritis. Infect. Immun. 61:4645-4653.

16. Martin, S. A., J. L. Karnovsky, J. M. Krueger, J. R. Pappenheimer, and K. Biemann. 1984. Peptidoglycans as promoters of slow wave sleep. 1. Structure of the sleep-promoting factor isolated from human urine. J. Biol. Chem. 259:7514-7522.

17. Mokrash, L. C. 1954 . Analysis of sugar phosphates and sugar mixtures with anthrone reagent. J. Biol. Chem. 193:685-699.

18. Ogawa, T., S. Kotani, S. Kusumoto, and T. Shiba. 1983. Possible chemotaxis of human monocytes by $N$-acetylmuramyl-L-alanyl-D-isoglutamine. Infect. Immun. 39:449-451.

19. Ohlsson, K., and I. Olsson. 1974. The neutral proteases of human granulocytes. Eur. J. Biochem. 42:519-527.

20. Sen, Z., and M. L. Karnovsky. 1984. Qualitative detection of muramic acid in normal mammalian tissues. Infect. Immun. 43:937-941.

21. Severijnen, A. J., J. Kool, A. J. G. Swaak, and M. P. Hazenberg. 1990. Intestinal flora of patients with rheumatoid arthritis: induction of chronic arthritis by cell wall fragments from isolated Eubacterium aerofaciens strains. Br. J. Rheumatol. 29:433-439.

22. Severijnen, A. J., R. van Kleef, M. P. Hazenberg, and J. P. van de Merwe.
1989. Cell wall fragments from major residents of the human intestinal flora induce chronic arthritis in rats. J. Rheumatol. 16:1061-1068.

23. Severijnen, A. J., R. van Kleef, M. P. Hazenberg, and J. P. van de Merwe. 1990. Chronic arthritis induced in rats by cell wall fragments of eubacterium species from intestinal flora. Infect. Immun. 58:523-528.

24. Smith, S. M., R. H. K. Eng, J. M. Campos, and H. Chmel. 1989. D-Lactic acid measurements in the diagnosis of bacterial infections. J. Clin. Microbiol. 27:385-388

25. Timmerman, C. P., E. Mattsson, L. Martinez-Martinez, L. de Graaf, J. A. G. van Strijp, H. A. Verburgh, J. Verhoef, and A. Fleer. 1993. Induction of release of tumor necrosis factor from human monocytes by staphylococci and staphylococcal peptidoglycans. Infect. Immun. 61:4167-4172.

26. Tipper, D. J. 1968. Akali-catalyzed elimination of D-lactic acid from muramic acid and its derivates and the determination of muramic acid. Biochemistry 7:1441-1449.

27. Tomasic, J., Z. Valinger, I. Hrsak, and B. Ladesic. 1986. Metabolic fate of peptidoglycan monomer from Brevibacterium divaricatum and biological activity of its metabolites, p. 203-214. In P. H. Seidl and K. H. Schleifer (ed.), Biological properties of peptidoglycan. Walter de Gruyter, New York.

28. Tondome, Y., H. Ohkuni, M. Mizuse, M. Furaya, S. Fujikawa, S. Tanaka, N. Watanabe, K. Fujii, and J. B. Zabrinsky. 1992. Detection of antibodies against streptococcal peptidoglycan and the peptide subunit (synthetic tetraD-alanyl-bovine serum albumin complex) in rheumatic-diseases. Int. Arch. Allergy Immunol. 97:301-307.

29. Weidel, W., and H. Pelzer. 1964. Bag-shaped macromolecules-new outlook on bacterial cell walls. Adv. Enzymol. 26:193-197.

30. Wilkinson, B. J., Y. Kim, and P. K. Peterson. 1981. Factors affecting complement activation by Staphylococcus aureus cell walls, their components, and mutants altered in teichoic acid. Infect. Immun. 32:216-224. 